\title{
Interactions between a marine dinoflagellate (Alexandrium catenella) and a bacterial community utilizing riverine humic substances
}

\author{
Per Carlsson ${ }^{1, *}$, Hélène Edling ${ }^{2}$, Christian Béchemin ${ }^{3}$ \\ ${ }^{1}$ University of Kalmar, Institute of Natural Sciences, Dept of Marine Sciences, Box 905, S-391 29 Kalmar, Sweden \\ ${ }^{2}$ University of Lund, Department of Limnology, Ecology Building, S-22362 Lund, Sweden \\ ${ }^{3}$ CNRS-IFREMER, BP 5, F-17137 L'Houmeau, France
}

\begin{abstract}
Dissolved organic matter in the form of riverine humic substances stimulated the growth of both axenic nitrogen-limited Alexandrium catenella cultures and nitrogen-limited cultures with a marine bacterial community present. The biomass increase of $A$. catenella could not be accounted for by utilization of inorganic nitrogen compounds. However, there was a considerable release of dissolved free and combined amino acids from the humic substances that was utilized by A. catenella. About $40 \%$ of the nitrogen used by $A$. catenella in the axenic treatment with humic substances added was taken up as organic nitrogen. Bacterial aminopeptidase and $\beta$-glucosidase activity was stimulated by the addition of humic substances and bacterial growth increased several-fold. Bacteria also utilized the released amino acids from the humic substances, but did not remineralize nitrogen, since no increase in ammonium concentrations could be detected in the bacteria treatments with humic substances added. In the axenic $A$. catenella treatment there was no significant aminopeptidase activity, suggesting that $A$. catenella was able to utilize the dissolved combined amino acids directly. Moreover, large fluorescently labeled dextran molecules $(2000 \mathrm{kDa})$ were taken up by $A$. catenella in the humic treatments, showing up in vacuoles inside the cells. These results suggests that $A$. catenella can grow well utilizing macromolecular organic compounds containing nitrogen, probably by a direct uptake
\end{abstract}

KEY WORDS: Alexandrium catenella - Dinoflagellates B Bacteria - DOM - Humic substances

\section{INTRODUCTION}

River runoff carries about $2.0 \times 10^{14} \mathrm{~g}$ of dissolved organic carbon (DOC) into the ocean annually (Deuser 1988). Thus, coastal waters adjacent to estuaries receive large quantities of dissolved organic matter (DOM). This riverine DOM is composed of 80 to $95 \%$ high-molecular-weight (HMW, $>1 \mathrm{kDa}$ ) polymeric compounds, such as polypeptides, polysaccharides and polyphenolic humic substances (HS) (Allen 1976, Thurman 1985). The HS also carry organically bound nutrients [nitrogen $(\mathrm{N})$ and phosphorus $(\mathrm{P})$ ] (Fleischer \& Stibe 1989, Thurman 1985) as well as dissolved amino acids and smaller carbohydrates (Münster \& Chróst 1990). HS, considered generally, consist of a

\footnotetext{
•E-mail: per.carlsson@ng.hik.se
}

nonhomogeneous material with polycyclic aromatic nuclei and attached polypeptides, carbohydrates, phenolic acids and metals, but the basic structure is still to a high degree unknown (Ziechmann 1988). The N content of riverine HS is usually 0.5 to $3 \%$ (by weight) and the $\mathrm{P}$ content is about $0.2 \%$ (Thurman 1985, Hedges 1987). Humic substances are usually defined operationally as the fraction of DOM that can be isolated by hydrophobic adsorption chromatography on non-ionic resins, such as XAD-8 (Thurman \& Malcolm 1983).

A part of the HMW DOM is available for bacterial utilization (Meyer et al. 1987, Tranvik 1990) due to hydrolyzation of the macromolecules by extracellular enzymes (e.g. Chróst 1991). Degradation of macromolecules with peptide bonds can occur by the action of bacterial leucine aminopeptidase (e.g. cleavage of amino acids from $\mathrm{N}$-terminal polypeptide chains) (Hoppe et al. 1988, Münster 1991). Since the highest 
extracellular enzyme activities usually are found in 0.2 to $2.0 \mu \mathrm{m}$ filtrates (Hollibaugh \& Azam 1983, Chróst \& Rai 1993) extracellular enzymes are considered to be associated to bacteria (Rosso \& Azam 1987), located in the periplasmic space or surface bound to the bacteria (Chróst 1991, Martinez \& Azam 1993). The products from the extracellular enzymatic activity should therefore be mainly available for the bacteria and not phytoplankton. However, extracellular enzymes can be washed away from the periplasmic space, liberated by lysis or damage of cells by grazers, and intracellular enzymes may also become dissolved by cell lysis or grazing (Chróst 1991). Higher aminopeptidase activities ( 10 to $90 \%$ of total activity) have also been measured in $0.2 \mu \mathrm{m}$ filtrates (Jakobsen \& Rai 1991). Bacterial aminopeptidase activity by enzymes no longer associated with the bacteria surface would then produce free amino acids also available for phytoplankton uptake.

Dissolved organic nitrogen (DON) is the dominant fraction of the flux of $\mathrm{N}$ from the land to the sea, generally making up 60 to $90 \%$ of the total $\mathrm{N}$-export (Meybeck 1982). DON is usually not considered as an available nutrient for phytoplankton when management of eutrophic coastal areas is discussed. However, several experiments have shown that DON stimulates phytoplankton production. Price et al. (1985) found that coastal phytoplankton in a stratified system increased more in particulate $\mathrm{N}$ than could be explained by the uptake of inorganic $\mathrm{N}$ and urea, presumably by utilization of DON. Granéli et al. (1985) suggested that the dinoflagellate Prorocentrum minimum was able to use the $\mathrm{N}$ in $\mathrm{HS}$, either directly or after bacterial remineralization, since the biomass yield of $P$. minimum increased considerably when HS and phosphate were added, and cellular $N$ content of $P$. minimum was comparable to cells grown with inorganic N. Riverine HS can also stimulate the coastal microbial food web, by increasing bacterial growth and subsequently the activity of bacterial grazers, increasing the regeneration of inorganic $N$ which in turn increases phytoplankton production (Carlsson \& Granéli 1993, Carlsson et al. 1995). There are also indications that some property of river water may be important for the development and persistence of blooms of dinoflagellates, since these blooms often start, or occur in coastal waters influenced by river runoff (Franks \& Anderson 1992, Fraga 1993, Moita 1993) and toxic blooms composed of Alexandrium tamarense form regularly in the outflow of 2 rivers in the Gulf of Maine (USA) and can persist in the plume for up to a month (Franks \& Anderson 1992).

The supply of $\mathrm{N}$ available for phytoplankton can also be regulated by bacterial uptake and regeneration of organic and inorganic $N$. The uptake of dissolved free amino acids (DFAA) by bacteria can exceed $60 \%$ of the total $\mathrm{N}$ uptake in coastal water and the uptake of DFAA can even exceed the requirement for growth (Hoch \& Kirchman 1995). However, when the concentration of DFAA is low, a larger part of the bacterial $\mathrm{N}$ demand can be supported by ammonium uptake (Hoch \& Kirchman 1995). The quality of the substrate will also direct the bacterial turnover of DOM. Bacteria will regenerate ammonium when the $C: N$ ratio of the substrate is low (Goldman et al. 1987, Kirchman et al. $1989)$ and utilize ammonium when the C:N ratio of the available substrate is high. When a N-limited system is supplied with riverine DOM with a high $C: N$ ratio it would therefore be expected that the bacteria would take up ammonium (assuming that the C:N ratio of the riverine DOM also reflects the availability of these compounds). However, the $\mathrm{C}$ in the riverine DOM might be more resistant to microbial degradation than the $\mathrm{N}$. A large part of the $\mathrm{N}$ in the isolated humic DOM can be rather loosely bound as ammonium, amino acids or precipitated polypeptides, easily utilizable for bacteria (Lytle \& Perdue 1981, Thurman 1985). Thus it is not easily predicted if bacteria would be assimilating or remineralizing $\mathrm{N}$ when supplied with a complex organic substrate with unknown $\mathrm{C}$ and $\mathrm{N}$ availability, such as riverine HS.

The occurrence of red tide forming Alexandrium spp. in coastal waters influenced by river runoff and the possibility that these dinoflagellates would be able to directly or indirectly utilize HS as an $N$ source was the basis for this experiment. Alexandrium spp. are considered to be mainly autotrophic in their nutrition, but ciliates and phytoplankton cells have been observed in food vacuoles in Alexandrium ostenfeldii (Jacobson \& Anderson 1996), showing that this species is also capable of mixotrophy.

We investigated whether Alexandrium catenella was able to grow with riverine HS as the major $N$ source in the medium without the presence of bacteria, by using the macromolecular HS by itself, or if bacterial utilization/remineralization of riverine HS would supply the dinoflagellate with more easily assimilated $N$ compounds such as ammonia and DFAA than the macromolecular HS.

\section{MATERIALS AND METHODS}

Isolation of humic substances. HS were isolated from water sampled (10 June 1995) close to the mouth of the river Fyllean in the county of Halland, Sweden. This river flows into the Laholm Bay, Kattegat on the Swedish west coast. The drainage area of the river is mainly covered with coniferous forest and the river water contains about 10 to $14 \mathrm{mg} \mathrm{l}^{-1}$ of DOC (Kullberg 
\& Petersen 1987). The river water was sampled using an acid washed polyethene bucket and the water sample (100 l) was transported to the laboratory in acid washed $25 \mathrm{l}$ polyethene containers and kept in a refrigerated room $\left(4^{\circ} \mathrm{C}\right)$ until processed further. Separation and concentration of HS were done according to Thurman \& Malcolm (1981) and Petersen et al. (1987). Within $24 \mathrm{~h}$ of sampling, the water was acidified to $\mathrm{pH} 1.8$ with $\mathrm{HCl}$ and filtered through 50 and $1 \mu \mathrm{m}$ cartridge filters (Brunswick Technetics Filterite) and passed through a XAD- 8 resin $(1000 \mathrm{ml}$, Amberlite) in a glass column at a rate of $100 \mathrm{ml} \mathrm{min}{ }^{-1}$. The humic material was then desorbed by back flushing the column with 2.5 bed volumes of $0.1 \mathrm{~mol} \mathrm{l}^{-1} \mathrm{NaOH}$ followed by immediate acidification to $\mathrm{pH} 2.5$. The $\mathrm{pH}$ was then adjusted to 7.0 with $\mathrm{NaOH}$ and the concentrated HS were frozen until use. Part of the humic concentrate was freeze-dried and the $\mathrm{N}$ and $\mathrm{C}$ content was analyzed using a Fisons NA $1500 \mathrm{CN}$ analyzer. The HS contained $0.30 \% \mathrm{~N}$ and $12.8 \% \mathrm{C}$ (by weight). The HS we isolated had a low $\mathrm{C}$ content compared to that which others have found before [about $50 \%$ of HS is usually $C$ according to Thurman (1985) and Hedges (1987)]. We therefore reanalyzed the HS for C and N content 3 times and also had a sample analyzed by another laboratory, with the same result.

Dinoflagellate culture. An axenic culture of Alexandrium catenella (CCMP 1598 from the ProvasoliGuillard culture collection) was cultured in a modified f/2 medium (Guillard \& Ryther 1962) as $1 / 40$ of the original composition (the inorganic N:P ratio was adjusted to 16:1). The medium thus contained $29 \mu_{\mathrm{mol} \mathrm{l}} \mathrm{l}^{-1}$ of $\mathrm{NO}_{3}^{-}$and $1.8 \mu \mathrm{mol} \mathrm{l} \mathrm{l}^{-1}$ of $\mathrm{PO}_{4}{ }^{3-}$. The salinity was $26 \%$. Cultures were kept at $16^{\circ} \mathrm{C}$, light intensity (PAR) $80 \mu \mathrm{mol} \mathrm{m} \mathrm{m}^{-2} \mathrm{~s}^{-1}$ (measured with a flat Li-Cor sensor) and a $12 \mathrm{~h}$ light: $12 \mathrm{~h}$ dark cycle. Axenity of the cultures was checked each week by direct bacteria counting using epifluorescence microscopy (see below).

Seawater sampling. Surface seawater (100 l, salinity $22 \%$ ) was collected using an acid washed polyethene bucket in Kattegat, Sweden on 9 March 1996. The salinity of the seawater was adjusted to $26 \%$ by addition of $\mathrm{NaCl}$. The water was then filtered through Whatman GF/F filters using a Millipore $90 \mathrm{~mm}$ filter holder, and through a $0.2 \mu \mathrm{m}$ Sartorius capsule filter. All water was then mixed in an acid washed $100 \mathrm{l}$ polyethene cylinder and distributed in acid washed 101 Pyrex glass flasks and autoclaved $\left(2 \mathrm{~h}, 121^{\circ} \mathrm{C}\right)$.

Experimental setup. The water was poured into 2.51 polycarbonate bottles that had previously been acid washed and autoclaved. The experimental setup was the following: Alexandrium catenella (axenic) (A), A. catenella (axenic) + HS (A+HS), A. catenella + bacteria (AB), A. catenella + bacteria + HS $(\mathrm{AB}+\mathrm{HS})$, bacteria (B), bacteria + HS (B+HS), control (only seawater) (C), control + HS (seawater $+\mathrm{HS})(\mathrm{C}+\mathrm{HS})$. All treatments were in 4 replicates.

For treatments with added bacteria, $2 \mathrm{l}$ of seawater was filtered through a Whatman GF/F glassfibre filter (approximate pore size $0.7 \mu \mathrm{m}$ ) and incubated at the experimental conditions for $3 \mathrm{~d}$. Bacterial numbers then increased to $4.04 \times 10^{6}$ cells $\mathrm{ml}^{-1}$ and $25 \mathrm{ml}$ of this bacterial suspension was added to the $2.5 \mathrm{l}$ autoclaved seawater for the bacterial treatments $11 \%$ inoculum corresponding to $0.04 \times 10^{6}$ bacteria $\left.\mathrm{ml}^{-1}\right)$. Phosphate was added to all treatments (to increase the concentration by $5 \mu \mathrm{mol} \mathrm{l}^{-1}$ ) in order to have a surplus of phosphate compared to the nitrogen present. Also trace metals and vitamins were added according to $1 / 10$ of the f/2 medium (Guillard \& Ryther 1962). The addition of HS increased the DOC concentration in the seawater from 1.3 to $10.2 \mathrm{mg} \mathrm{l}^{-1}$, which can be considered as a natural increase in estuarine waters on the Swedish west coast, since open waters in the Kattegat/ Skagerrak have DOC concentrations of up to $4 \mathrm{mg} \mathrm{l}^{-1}$ (Wedborg et al. 1994), and the concentration in rivers entering the coastal zone can be considerably higher than $10 \mathrm{mg} \mathrm{l}^{-1}$ (Petersen et al. 1987, Andersson et al. 1991).

The cultures were then incubated at $16^{\circ} \mathrm{C}$ and a $12 \mathrm{~h}$ light:12 h dark cycle. The light intensity (PAR) was $80 \mu \mathrm{mol} \mathrm{m} \mathrm{m}^{-2} \mathrm{~s}^{-1}$.

Dinoflagellate and bacteria enumeration and bacterial cell volumes. Phytoplankton samples $(10 \mathrm{ml})$ were fixed with acid Lugol's solution ( $1 \%$ final concentration) and cells were counted using $2.4 \mathrm{ml}$ settling chambers and a Nikon Optiphot inverted microscope equipped with a $40 \times \mathrm{Ph} 3$ objective. At least 200 Alexandrium catenella cells were counted in each sample. Growth rates for $A$. catenella were calculated using the formula $\mu=\left(\ln N_{t 2}-\ln N_{t 1}\right) / \Delta t$, where $N_{t 1}$ and $N_{12}$ are cell numbers initially and finally and $\Delta t$ is the time interval (in days) between $N_{t 1}$ and $N_{t 2}$. Bacteria were counted by staining a $2 \mathrm{ml}$ subsample (fixed with formaldehyde, $1 \%$ final concentration) of each culture with the DNA-specific fluorochrome DAPI $\left(20 \mu \mathrm{g} \mathrm{ml}^{-1}\right.$ final concentration) and filtering the bacteria onto $0.2 \mu \mathrm{m}$ black polycarbonate filters (Poretics Inc.) for direct enumeration of bacteria by epifluorescence microscopy (Porter \& Feig 1980). Bacteria were counted using a Nikon Optiphot-2 epifluorescence microscope with a Nikon Ph 4 DL $100 \times / 1.30$ oil immersion objective and the following filter combination: excitation 360 to $370 \mathrm{~nm}$, barrier filter $420 \mathrm{~nm}$ and dichroic mirror $400 \mathrm{~nm}$. At least 250 bacteria were counted on each filter. Growth rates were calculated as for $A$. catenella. Bacterial images were acquired with an Olympus BX50 epifluorescence microscope equipped with Olympus UPlanFI $100 \times / 1.30$ oil immersion objective and an Optronics VI-470 CCD video camera system 
(Optronics Engineering). Digital 24-bit color pictures in PICT format were obtained with ImageGrabber-24 (Neotech Ltd) and further processed with IPLab Spectrum 3.1 software (Signal Analytics). The biovolume of at least 200 cells from the initial and final samples was measured. To measure the biovolume of an average bacterial cell, a slightly modified algorithm of Ramsing et al. (1996) was applied. Differences from the original algorithm were: (1) no background subtraction operation was used, (2) only the green color fraction of the image was analyzed as it gave the best separation, (3) cell edges were detected by thresholding the second derivative with the lowest possible value, 1.0, and (4) overlapping cells were not analyzed.

Chemical analyses. Inorganic nutrients $\left(\mathrm{NO}_{3}{ }^{-}+\mathrm{NO}_{2}{ }^{-}\right.$, $\left.\mathrm{NH}_{4}{ }^{+}, \mathrm{PO}_{4}{ }^{3-}\right)$ were analyzed manually using standard procedures (Valderrama 1995). Absorbance was measured using a Beckman DU 650 spectrophotometer equipped with a $10 \mathrm{~mm}$ flow-through quartz cell. Standard curves using 5-point calibration in the concentration interval of the samples were established at each analysis. Nitrate was reduced to nitrite using a micro cadmium column (volume $2 \mathrm{ml}$ ) and a peristaltic pump (Ismatec) in order to reduce sample volume to $10 \mathrm{ml}$. Flow rate of the peristaltic pump was set to $1.0 \mathrm{ml} \mathrm{min}^{-1}$ in order to optimize the reduction of nitrate to nitrite.

Samples (200 to $300 \mathrm{ml}$ ) for particulate $\mathrm{C}$ and $\mathrm{N}$ were filtered onto precombusted $\left(450^{\circ} \mathrm{C}, 2 \mathrm{~h}\right)$ Whatman GF/F filters and analyzed in a Fisons NA $1500 \mathrm{CN}$ analyzer.

Samples for DOC, DFAA, dissolved combined amino acids (DCAA) and total dissolved carbohydrates (TDCHO) (30 ml for each analysis) were gravity filtered onto precombusted $\left(450^{\circ} \mathrm{C}, 2 \mathrm{~h}\right)$ Whatman $\mathrm{GF} / \mathrm{F}$ filters using $50 \mathrm{ml}$ glass syringes and Swinnex filtering holders previously washed in hydrogen peroxide (12 h) to degrade traces of organic matter. The filtrates were distributed in duplicate hydrogen peroxide washed polyethylene scintillation vials for each sample and frozen $\left(-20^{\circ} \mathrm{C}\right)$ before analysis.

Dissolved organic carbon concentrations were measured spectrophotometrically according to Pages \& Gadel (1990), using a Beckman DU 650 spectrophotometer equipped with a $10 \mathrm{~mm}$ quartz flow-through cell. By this method the DOC concentration is calculated using the slope ( $\mathrm{S}^{\circ}$ ) of the absorption between 250 to $360 \mathrm{~nm}$ and the absorption at $254 \mathrm{~nm}$.

DFAA were analyzed without sample pretreatment using flow injection sample processing according to Petty et al. (1982), after fluorescence derivatization with a carrier stream of o-phthalaldehyde (OPA) according to Roth (1971) and Lindroth \& Mopper (1979). Results are reported in glycine equivalents. Concentrations of DCAA were determined after hydrolysis with 5 to $6 \mathrm{M} \mathrm{HCl}$ at $100^{\circ} \mathrm{C}$ for 20 to $24 \mathrm{~h}$ and then mea- suring the concentration of DFAA in the hydrolysate and subtracting the predetermined concentrations of DFAA.

TDCHO were quantified using the spectrophotometric method of Johnson \& Sieburth (1977), in which the reduction of free monosaccharides to sugar alcohols with $\mathrm{KBH}_{4}$, and periodate oxidation to formaldehyde. gives a colored complex with the 3 -methyl-2 benzothiazolinone hydrazone hydrochloride (MBTH). Results are reported as glucose equivalents after subtraction of a blank value and comparison with a standard curve.

Total dissolved nitrogen was analyzed according to Valderrama (1995) and the DON concentration was calculated as the difference between total dissolved nitrogen and the sum of inorganic nitrogen $\left(\mathrm{NO}_{3}{ }^{-}+\right.$ $\mathrm{NO}_{2}{ }^{-}, \mathrm{NH}_{4}{ }^{+}$).

Enzyme activities. Total (free and cell associated) extracellular aminopeptidase and $\beta$-glucosidase activity were measured by adding L-leucine 7 -amido- 4 methylcoumarin and 4-methylumbelliferyl- $\beta$-glucopyranoside (SIGMA) (200 $\mathrm{umol} \mathrm{l}^{-1}$ final concentration), and following the enzymatic release of the fluorescent products 7-amino-4-methylcoumarin (AMC) and 4methylumbelliferone (MUF) (Hoppe 1983, Chróst 1991). The samples were incubated for 1 to 2.5 and 14 to $18 \mathrm{~h}$, respectively in the dark at $21^{\circ} \mathrm{C}$ and produced AMC and MUF were measured at 320 to $390 \mathrm{~nm}$ excitation, 430 to $485 \mathrm{~nm}$ emission, using a Turner 112 filter fluorometer. Calibration curves were prepared for each treatment (media with or without HS). Preliminary kinetic experiments verified that a final substrate concentration of 150 to $180 \mu \mathrm{mol} \mathrm{l^{-1 }}$ was enough to reach enzyme-substrate saturation. Thus, the reported enzyme activities are the $V_{\max }$ of the enzymes. Blanks for each treatment were microwaved $(3 \times 5 \mathrm{~min}$, to boiling point) to coagulate the enzymes before adding the substrate (Mayer 1989).

\section{RESULTS}

\section{Growth of Alexandrium catenella}

Alexandrium catenella showed the highest growth in the axenic treatment with HS added $(\mathrm{A}+\mathrm{HS})$ and in the treatment with bacteria and $\mathrm{HS}(\mathrm{AB}+\mathrm{HS})$ (Fig. 1). In these treatments the inoculum of 50 cells $\mathrm{ml}^{-1}$ of $A$. catenella increased to $504 \pm 81$ (mean \pm SD) and $455 \pm$ 57 cells $m^{1-1}$, respectively at Day 10 of the experiment. This corresponds to a specific growth rate of 0.27 $\left(=0.36\right.$ doublings $\left.\mathrm{d}^{-1}\right)$. The apparent lower cell number of $A$. catenella in the humic treatments with bacteria $(\mathrm{AB}+\mathrm{HS})$ compared with the humic treatment without bacteria $(A+H S)$ at the end of the experiment was not significant ( $p>0.05$, Mann-Whitney $U$-test). In the 

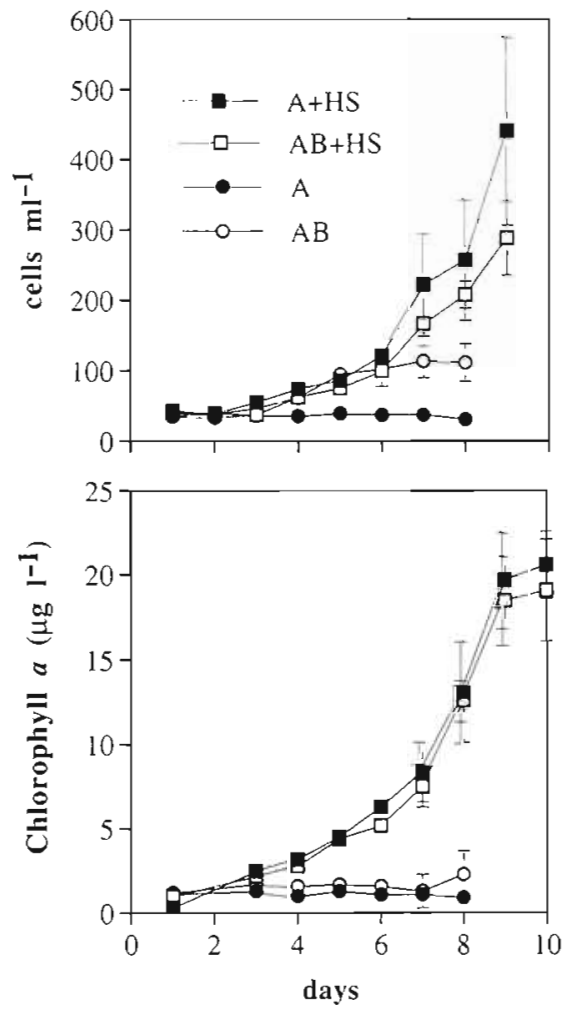

Fig. 1. Cell concentration of Alexandrium catenella and chlorophyll a concentration. $\mathrm{A}=\mathrm{A}$. catenella (axenic treatment), $\mathrm{AB}=A$. catenella + bacteria $\mathrm{HS}=$ addition of humic substances $(n=4$, mean $\pm S D)$

treatments without extra HS added [the axenic $A$. catenella treatment (A) and the $A$. catenella with bacteria $(A B)]$, the final cell numbers were only $31 \pm 3$ and $112 \pm 27$ cells $\mathrm{ml}^{-1}$, respectively, i.e. growth rates were much lower $\left(0\right.$ and $0.16\left[=0.21\right.$ doublings $\left.\left.\mathrm{d}^{-1}\right]\right)$. The higher cell numbers of $A$. catenella in the $A B$ treatment compared with the A treatment was significant $(\mathrm{p}<$ 0.05, Mann-Whitney $U$-test).

The chlorophyll a concentration in the different treatments showed the same pattern as cell numbers (Fig. 1). Chlorophyll a content per cell during the experiment was highest in the $\mathrm{A}+\mathrm{HS}$ and $\mathrm{AB}+\mathrm{HS}$ treatments ( 40 to $60 \mathrm{pg}$ chl a cell ${ }^{-1}$ compared to the $A$ and $\mathrm{AB}$ treatments (10 to $20 \mathrm{pg}$ chl a cell ${ }^{-1}$ ).

Particulate $C$ concentration on day 10 for the $A+H S$ treatment was $990 \mu \mathrm{g} \mathrm{C} \mathrm{l^{-1 }}$ when the control $(\mathrm{C}+\mathrm{HS})$ was subtracted. The carbon content of Alexandrium catenella cells calculated from this value and the final cell number in the A+HS treatment was $1960 \mathrm{pg} \mathrm{C}$ cell $^{-1}$, which is similar to the value obtained $(1840 \mathrm{pg} \mathrm{C}$ cell $^{-1}$ ) using the microscopical measurements of the linear dimensions (diameter $30 \mu \mathrm{m}$ and assuming the cell being spherical) and the conversion factor (0.13) for thecate dinoflagellate cell volume into cell $\mathrm{C}$ (Smetacek 1975).

\section{Bacterial growth}

The number of bacteria increased rapidly in the treatments with HS (Fig. 2) and reached $2.5 \pm 0.3 \times 10^{6}$ cells $\mathrm{ml}^{-1}$ in the $\mathrm{AB}+\mathrm{HS}$ treatment and $2.0 \pm 0.4 \times 10^{6}$ cells $\mathrm{ml}^{-1}$ in the $\mathrm{B}+\mathrm{HS}$ treatment on Day 9 . In the same treatments the bacterial specific growth rates in the exponential phase were $0.83 \pm 0.07 \mathrm{~d}^{-1}$ and $1.2 \pm$ $0.06 \mathrm{~d}^{-1}$, respectively. Without $\mathrm{HS}$ addition the bacterial cell numbers increased only to $0.7 \pm 0.05 \times 10^{6}$ cells $\mathrm{ml}^{-1}$ in the $\mathrm{AB}$ treatment and $0.8 \pm 0.2 \times 10^{6}$ cells $\mathrm{ml}^{-1}$ in the $B$ treatment. This corresponds to a specific growth rates in the exponential growth phase of $0.31 \pm 0.18$ and $0.30 \pm 0.07 \mathrm{~d}^{-1}$, respectively. In the treatments where bacteria were not supposed to be present ( $\mathrm{C}$ and $\mathrm{C}+\mathrm{HS}$ ), a maximum of $0.002 \times 10^{6}$ bacteria $\mathrm{ml}^{-1}$ could be detected at the end of the experiment. We therefore assume that these treatments were without influence of bacterial activity during the experimental period. The apparent higher bacterial biomass in the $\mathrm{AB}+\mathrm{HS}$ treatment than in the $\mathrm{B}+\mathrm{HS}$ treatment at the end of the experiment was not significant $(p>0.05$, Mann-Whitney $U$-test). Mean bacterial cell volumes were initially $0.25 \pm 0.15 \mu^{3}$ and had not changed significantly in any of the treatments on the last day of the experiment ( $p>0.05$, Mann-Whitney $U$-test).

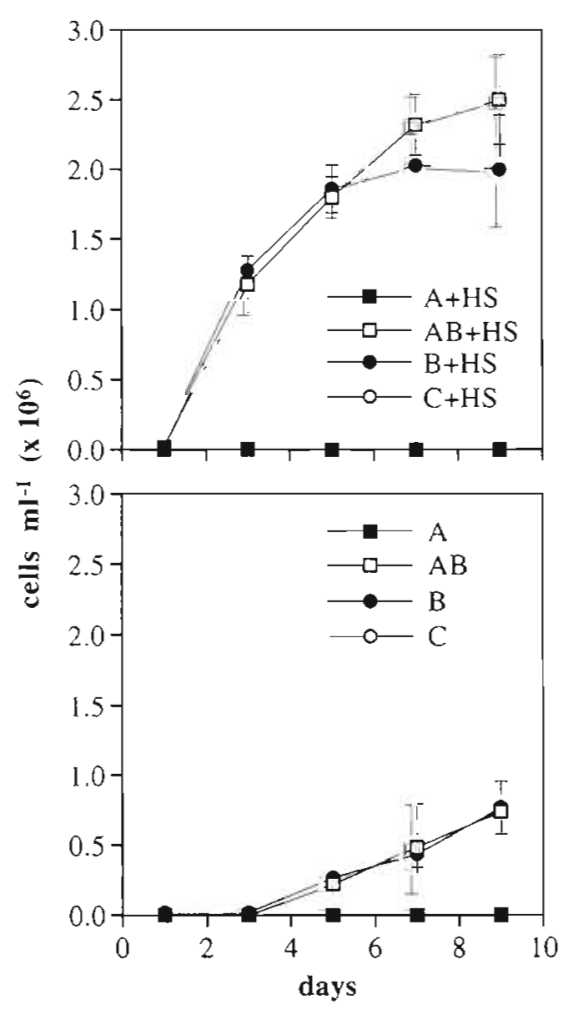

Fig. 2. Bacterial abundance. $\mathrm{A}=$ Alexandrium catenella (axenic), $\mathrm{AB}=\mathrm{A}$. catenella + bacteria, $\mathrm{B}=$ bacteria, $\mathrm{C}=$ control, $\mathrm{HS}=$ addition of humic substances $(n=4$, mean $\pm S D)$ 


\section{Inorganic nutrients}

Initially ammonium concentrations were 0.9 to $1.1 \mu \mathrm{mol} \mathrm{l^{-1 }}$ in the HS treatments, while they were 0.2 to $0.4 \mu \mathrm{mol} \mathrm{l}^{-1}$ in the treatments without HS added (Fig. 3). In the sterile controls with $\mathrm{HS}$ added (C+HS), there was a significant net release of ammonium (net concentration increase was $1.8 \mu \mathrm{mol} \mathrm{l} \mathrm{l}^{-1}$ during the experiment). Assuming that this release of ammonium also took place in the treatments with organisms, the released ammonium in these treatments was utilized by Alexandrium catenella and bacteria, since the ammonium concentration in these treatments was always below $0.5 \mu \mathrm{mol} \mathrm{I}^{-1}$.

Initial nitrate concentrations varied between 1.4 and $2.9 \mu \mathrm{mol} \mathrm{l}^{-1}$ for the controls without any addition and the treatments with Alexandrium catenella, bacteria and HS added (Fig. 3). Nitrate concentrations decreased during the experiment in all treatments, and were between 0.5 and $1.5 \mu \mathrm{mol} \mathrm{l}^{-1}$ at the end of the experiment. The lowest concentration was found in the A. catenella treatments with HS. Nitrate concentrations in the treatments without HS added were similar to those in the treatments with HS added and no release of nitrate from the HS was observed in the $\mathrm{C}+\mathrm{HS}$ treatment.

Initial phosphate concentrations were between 4.5 and $5.8 \mu \mathrm{mol} \mathrm{l}^{-1}$ after the extra addition of phosphate.

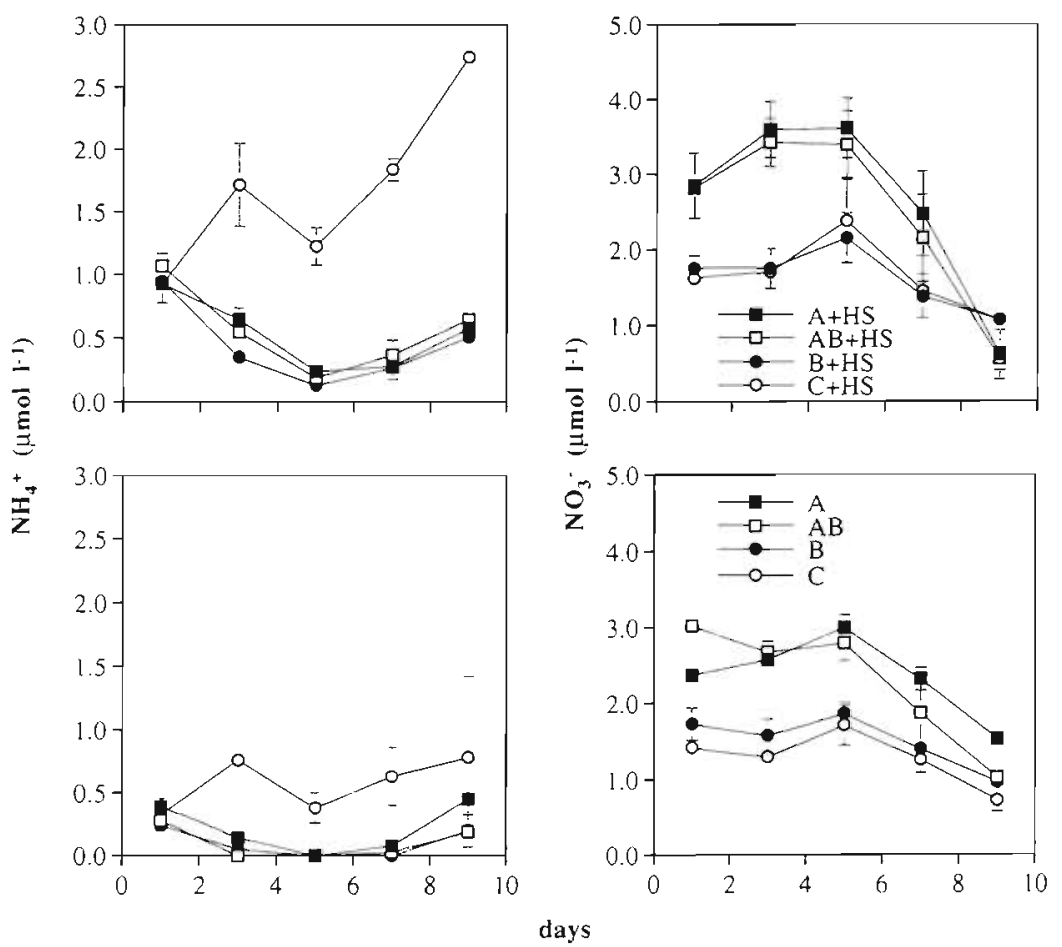

Fig. 3. Ammonium and nitrate concentrations. Treatments as in Fig. 2 ( $n=4$ mean \pm SD)
Phosphate concentrations then stayed above $3 \mu \mathrm{mol} \mathrm{l}^{-1}$ during the whole experiment (data not presented), which means that there was always a surplus of phosphate compared to inorganic and organic $\mathrm{N}$ (total dissolved $\mathrm{N}: \mathrm{PO}_{4}{ }^{3-}$ was always below 16 ), concerning the requirements of bacteria and Alexandrium catenella.

\section{Particulate $\mathrm{C}$ and $\mathrm{N}$}

The addition of HS increased the particulate $\mathrm{C}$ and $\mathrm{N}$ of the initial seawater (from $3.1 \pm 1.6$ to $10.9 \pm 1.3 \mu \mathrm{mol}$ $\mathrm{C}^{-1}$ and from $0.4 \pm 0.2$ to $0.8 \pm 0.2 \mu \mathrm{mol} \mathrm{N} \mathrm{l^{-1 }}$, respectively) (Table 1). This increase was very small, compared to the increase in bacteria and dinoflagellate particulate $\mathrm{C}$ and $\mathrm{N}$ during the experiment. In the axenic Alexandrium catenella + HS treatment $(\mathrm{A}+\mathrm{HS})$, the particulate $N$ increased from $2.8 \pm 0.3$ to $10.1 \pm$ $1.1 \mu \mathrm{mol} \mathrm{l}^{-1}$ during the experiment. This corresponds to an algal uptake of about $7.3 \mu \mathrm{mol} \mathrm{N} \mathrm{l}^{-2}$. Matsuda et al. (1996) found that the $N$ content in $A$. catenella cells varied with growth rate. At a growth rate of $0.3 \mathrm{~d}^{-1}$ (as the growth rate of $A$. catenella in our $A+H S$ treatment), Matsuda et al. (1996) found that the cells had an $N$ quota of $13 \mathrm{pmol} \mathrm{N}$ cell $^{-1}$. This would correspond to a

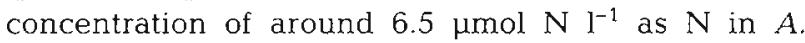
catenella cells ( 500 cells $\mathrm{ml}^{-1}$ ) in the $\mathrm{A}+\mathrm{HS}$ treatment at the end of the experiment, which is in good agreement with our estimate based on particulate $\mathrm{N}$ analysis. The uptake of inorganic $\mathrm{N}$ in the A+HS treatment by $A$. catenella was approximately $4.4 \mathrm{\mu mol} \mathrm{l}^{-1}$ (the difference between initial concentration of inorganic $N$ and final in the $A+H S$ treatment plus the net release of ammonium in the C+HS treatment). Since the net increase in particulate $N$ concentration of $A$. catenella cells in the $A+H S$ treatment was $7.3 \mu \mathrm{mol} \mathrm{l}^{-1}$, A. catenella also used DON in this treatment. The DON would then have supplied $A$. catenella with around $7.3-$ $4.4=2.9 \mu \mathrm{mol} \mathrm{l}^{-1}$ of $\mathrm{N}$ which is equivalent to $40 \%$ of the total $\mathrm{N}$ increase in A. catenella cells.

In the axenic Alexandrium catenella treatment without $\mathrm{HS}$ added $(A)$, there was instead a net loss of particulate $\mathrm{N}$ during the experiment (from $1.0 \pm 0.2$ to $0.2 \pm 0.1 \mu \mathrm{mol} \mathrm{N} \mathrm{^{-1 }}$ ), due to the absence of algal growth in this treatment.

In the $\mathrm{B}+\mathrm{HS}$ treatment, there were significantly higher particulate $\mathrm{C}$ and $\mathrm{N}$ concentrations $\left(56.5 \pm 5.3 \mu \mathrm{mol} \mathrm{C} \mathrm{l^{-1 }}\right.$ and $6.5 \pm 1.3 \mu \mathrm{mol} \mathrm{N} \mathrm{l}^{-1}$, respectively) 
Table 1 Particulate $C$ and $N\left(\mu m o l ~^{-1}\right)$ at Day 1 and Day 5 for the $A$ treatment, Day 8 for the AB treatment and Day 9 for the other treatments (final). $\mathrm{A}=$ Alexandrium catenella (axenic), $\mathrm{AB}=\mathrm{A}$. catenella + bacteria, $\mathrm{B}=\mathrm{bacteria}, \mathrm{C}=\mathrm{control}, \mathrm{HS}=$ humic substances added. (Mean $\pm \mathrm{SD}, \mathrm{n}=4$ )

\begin{tabular}{|lrccccc|}
\hline Treatment & C (Day 1) & N (Day 1) & C/N (Day 1) & C (final) & $N$ (final) & C/N (final) \\
\hline A+HS & $23.3 \pm 2.5$ & $2.8 \pm 0.3$ & $8.4 \pm 0.6$ & $116.2 \pm 11.9$ & $10.1 \pm 1.1$ & $11.5 \pm 0.5$ \\
AB+HS & $23.5 \pm 3.2$ & $3.1 \pm 0.4$ & $7.6 \pm 0.1$ & $138.8 \pm 19.6$ & $15.1 \pm 2.0$ & $10.2 \pm 1.4$ \\
B+HS & $8.4 \pm 1.5$ & $1.1 \pm 0.4$ & $7.6 \pm 1.5$ & $56.5 \pm 5.3$ & $6.5 \pm 1.3$ & $8.9 \pm 0.8$ \\
C+HS & $10.9 \pm 1.3$ & $0.8 \pm 0.2$ & $14.2 \pm 2.7$ & $33.9 \pm 0.6$ & $1.0 \pm 0.1$ & $33.4 \pm 3.9$ \\
A & $11.4 \pm 1.0$ & $1.0 \pm 0.2$ & $11.8 \pm 1.3$ & $10.5 \pm 2.0$ & $0.2 \pm 0.1$ & $62.2 \pm 27.2$ \\
AB & $13.4 \pm 1.1$ & $1.4 \pm 0.1$ & $9.9 \pm 0.4$ & $36.1 \pm 12.7$ & $4.0 \pm 0.4$ & $9.6 \pm 1.4$ \\
B & $5.3 \pm 1.6$ & $0.4 \pm 0.2$ & $12.6 \pm 1.9$ & $12.8 \pm 3.0$ & $1.4 \pm 0.4$ & $9.3 \pm 0.7$ \\
C & $3.1 \pm 1.6$ & $0.4 \pm 0.2$ & $7.8 \pm 1.1$ & $6.6 \pm 0.8$ & $0.8 \pm 0.1$ & $8.1 \pm 0.9$ \\
\hline
\end{tabular}

than in the $\mathrm{B}$ treatment $\left(12.8 \pm 3.0 \mu \mathrm{mol} \mathrm{C} \mathrm{l}{ }^{-1}\right.$ and $1.4 \pm$ $0.4 \mu \mathrm{mol} \mathrm{N} \mathrm{I}^{-1}$, respectively) at the end of the experiment due to bacterial growth using HS as substrate. Estimated as above, using particulate $\mathrm{N}$ concentrations, bacterial uptake was about $5.1 \mu \mathrm{mol} \mathrm{N}{ }^{-1}$ in the $\mathrm{B}+\mathrm{HS}$ treatment. If the bacterial $\mathrm{N}$-uptake instead is estimated using the number of bacteria in the $\mathrm{B}+\mathrm{HS}$ treatment at the end of the experiment (around $2 \times$ $10^{6}$ bacteria $\mathrm{ml}^{-1}$ ), the mean bacterial biovolume $\left(0.25 \mathrm{\mu m}^{3}\right)$ and a conversion factor of $110 \mathrm{fg} \mathrm{N} \mathrm{Nm}^{-3}$ (obtained for a marine bacterial community by Lee \& Fuhrman 1987), the bacterial $N$ content at the end of the experiment corresponds to a concentration of $3.9 \mu \mathrm{mol} \mathrm{N}{ }^{-1}$. However, since the bacterial $\mathrm{N}$ content per biovolume varies widely (between 7 and $220 \mathrm{fg} \mathrm{N}$ ${\mu \mathrm{m}^{-3}}^{3}$, according to references in Lee 1993), this calculation is probably not so accurate as our estimate of bacterial $\mathrm{N}$-uptake based on the particulate $\mathrm{N}$ increase in the $\mathrm{B}+\mathrm{HS}$ treatment.

The $\mathrm{C}: \mathrm{N}$ ratio of the particulate material was between $7.6 \pm 1.5$ and $14.2 \pm 2.7$ initially, with the lowest ratio for the treatments with bacteria and the highest ratio for the control with HS addition (Table 1). The rather high C:N ratio in the treatments with only bacteria indicates that a significant proportion of the material on the GF/F filters was of detrital character, since bacterial C:N ratios usually are around 4 or 5 (references in Lee 1993). At the end of the experiment the $\mathrm{C}: \mathrm{N}$ ratio was $11.5 \pm$ 0.5 in the A+HS treatment and significantly higher in the $\mathrm{A}$ treatment $(62.2 \pm 27.2)$. However, the final C:N ratio in the $A B+H S$ treatment was not significantly different from the $\mathrm{AB}$ treatment $(10.2 \pm 1.4$ and $9.6 \pm 1.4$, respectively). Also, in the $\mathrm{B}+\mathrm{HS}$ and the $B$ treatments, the final $\mathrm{C}: \mathrm{N}$ ratio was not significantly different $(8.9 \pm$ 0.9 and $9.3 \pm 0.8$, respectively).

\section{Dissolved organic nitrogen and dissolved organic carbon}

DON concentration increased by $16.9 \pm 2.7 \mu \mathrm{mol} \mathrm{l}^{-1}$ due to the addition of HS (Table 2), which is close to the estimated increase calculated using the analyzed $\mathrm{N}$ content in the HS. The calculated DOC concentration in the seawater used for the cultures was around $108 \pm 16 \mu \mathrm{mol} \mathrm{l}^{-1}$ and increased to $808 \pm 25 \mu \mathrm{mol} \mathrm{l} \mathrm{l}^{-1}$ after the addition of HS (Table 2). The addition of HS thus increased the DOC concentration by $700 \mu \mathrm{mol} \mathrm{l}^{-1}$ $\left(8.9 \mathrm{mg} \mathrm{l}^{-1}\right.$ ). Since the content of $\mathrm{C}$ in the freeze-dried HS was $12 \%$ the total concentration of HS should have been $(8.9 / 12) \times 100=74 \mathrm{mg} \mathrm{l}^{-1}$. According to the analysis of freeze-dried HS, $0.3 \%$ of this was $\mathrm{N}$ and then $(0.3 \times 74) / 100=0.222 \mathrm{mg} \mathrm{N} \mathrm{l}^{-1}$ was added. This is

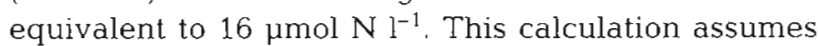
that all $\mathrm{C}$ added as HS was dissolved. The difference between the calculated particulate $\mathrm{C}$ concentration of the $\mathrm{C}+\mathrm{HS}$ treatment and the $\mathrm{C}$ treatment was only $7.8 \mu \mathrm{mol} \mathrm{C} \mathrm{l}^{-1}$. Thus only $1 \%$ of the added HS carbon was caught initially on the GF/F filters used for separating dissolved and particulate $C$, and this assumption can be made.

The DON concentration decreased during the experiment in all treatments with organisms present, and

Table 2. Dissolved organic carbon (DOC) and dissolved organic nitrogen (DON) $\left(\mu \mathrm{mol} \mathrm{l}^{-1}\right)$ at Day 1 and Day 9. Treatments as in Table 1. (Mean $\left.\pm S D, n=4\right)$

\begin{tabular}{|lcccc|}
\hline Treatment & DOC (Day 1) & DON (Day 1) & DOC (Day 9) & DON (Day 9) \\
\hline A +HS & $850 \pm 16$ & $40.1 \pm 4.3$ & $825 \pm 16$ & $31.5 \pm 10.9$ \\
AB+HS & $908 \pm 33$ & $39.2 \pm 1.4$ & $875 \pm 8$ & $31.1 \pm 2.1$ \\
B+HS & $858 \pm 16$ & $35.8 \pm 1.1$ & $883 \pm 8$ & $37.5 \pm 3.9$ \\
C+HS & $808 \pm 25$ & $40.4 \pm 2.7$ & $775 \pm 8$ & $40.4 \pm 3.0$ \\
A & $125 \pm 8$ & $26.5 \pm 0.8$ & $133 \pm 8$ & $25.6 \pm 4.2$ \\
AB & $108 \pm 8$ & $26.7 \pm 1.4$ & $116 \pm 8$ & $19.8 \pm 2.7$ \\
B & $108 \pm 8$ & $25.6 \pm 3.2$ & $116 \pm 16$ & $18.0 \pm 2.8$ \\
C & $108 \pm 16$ & $23.5 \pm 2.5$ & $116 \pm 16$ & $24.8 \pm 1.5$ \\
& & & & \\
\hline
\end{tabular}


this decrease in DON concentration roughly corresponds to the increase in particulate $\mathrm{N}$ during the experiment. However, with the high variability of the results from the DON analysis, it is not possible to make an accurate estimate of the uptake of DON by Alexandrium catenella. Instead we have used the increase in particulate $\mathrm{N}$ to estimate this (see 'Results: Particulate $C$ and $N^{\prime}$ ')

DOC concentrations did not decrease as the DON concentrations during the experiment, even if a higher concentration of particulate $C$ could be detected in all treatments (except the $\mathrm{A}$ treatment) at the end of the experiment. However, only a small part of the DOC would become particulate $C$ and this was probably undetectable by the method we used. For the $\mathrm{C}+\mathrm{HS}$ treatment, the increase in particulate $C$ (presumably by flocculation) was $29 \mu \mathrm{mol} \mathrm{l} \mathrm{l}^{-1}$ which is only $3 \%$ of the initial DOC concentration $\left(808 \mu \mathrm{mol}^{-1}\right.$ ). In the treatment with the highest increase in particulate $C$ (and
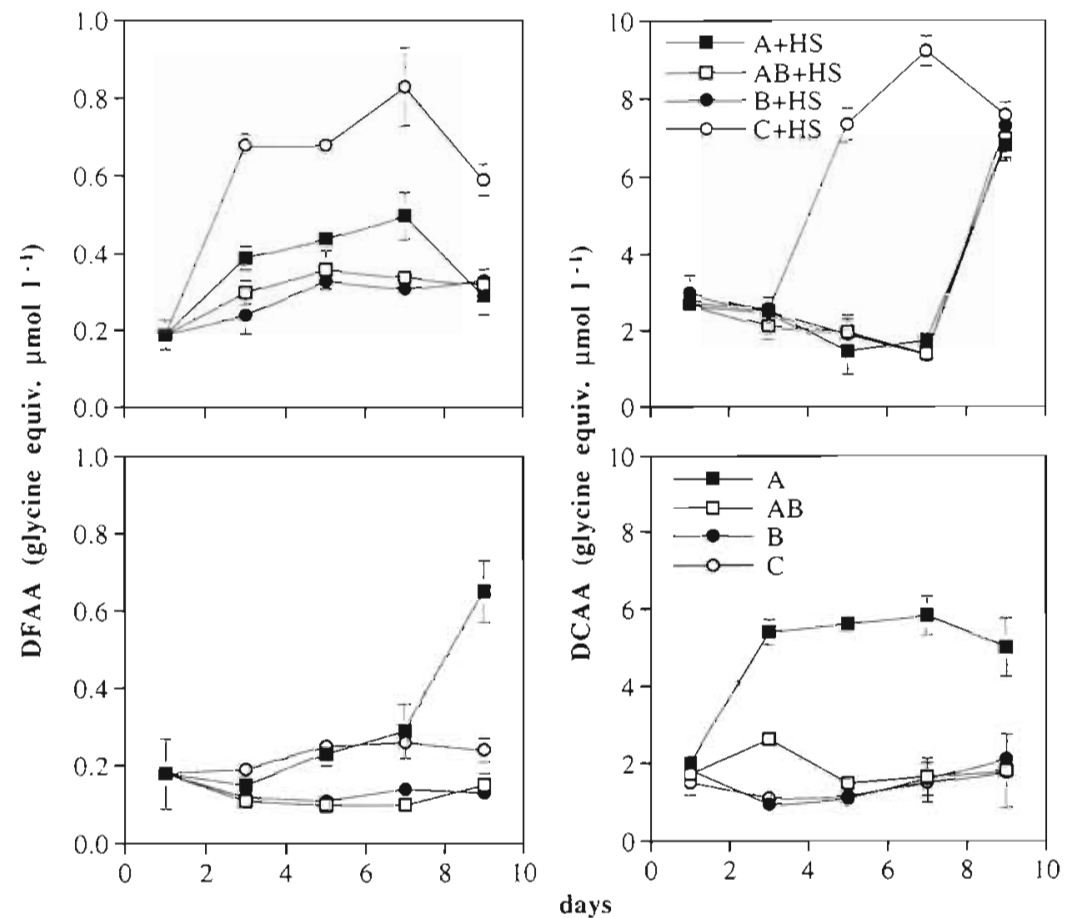

Fig. 4. Concentrations of dissolved free amino acids (DFAA) and dissolved combined amino acids (DCAA). Treatments as in Fig. $2(n=4$, mean \pm SD) no photosynthetic conversion of dissolved inorganic $C$ to particulate $C$, i.e. the $\mathrm{B}+\mathrm{HS}$ treatment), the particulate $\mathrm{C}$ concentration increased $48 \mathrm{mmol} \mathrm{l}^{-1}$, which corresponds to $6 \%$ of the initial DOC concentration, but still the precision of the method we used for analyzing DOC concentrations (Pages \& Gadel 1990) was not good enough to detect the presumed change in DOC concentration. This is in accordance with other studies that have shown that only a few percent of the DOC pool is utilizable by bacteria and can usually not be detected even using the high temperature catalytic analysis of DOC (Coffin et al. 1993). Instead, initial DOC concentration, oxygen consumption by bacteria and bacterial production (e.g. leucine uptake) should preferably be used to calculate bacterial utilization of DOC (Amon \& Benner 1996).

\section{Dissolved free and combined amino acids (DFAA and DCAA, glycine equivalents)}

There was a slight increase in DFAA concentration in all HS treatments containing organisms (from $0.2 \mu \mathrm{mol}$ $\mathrm{I}^{-1}$ initially to up to $0.4 \mathrm{\mu mol} \mathrm{I}^{-1}$ ) during the experiment (Fig. 4). However, the DFAA concentration increased more in the control with HS added (up to $0.8 \mu \mathrm{mol} \mathrm{l}^{-1}$ ). We assume that the same amount of DFAA was liberated from the HS in the treatments with organisms, but that the utilization of DFAA by bacteria and Alexandrium catenella kept the concentration of DFAA lower

in these treatments. In the treatments without $\mathrm{HS}$ added, the concentration of DFAA decreased to approximately $0.1 \mu \mathrm{mol} \mathrm{l}^{-1}$ in the treatments with bacteria ( $B$ and $A B$ ). In the treatments with $A$. catenella the concentration instead was stable around $0.2 \mu \mathrm{mol} \mathrm{l}^{-1}$, except for the last day in the A treatment, when the concentration of DFAA increased to $0.6 \mu \mathrm{mol} \mathrm{l}^{-1}$, probably due to release of DFAA from $A$. catenella cells.

The concentration of DCAA decreased from $2.7-3.0 \mu \mathrm{mol} \mathrm{l} \mathrm{l}^{-1}$ to $1.4-1.7 \mu \mathrm{mol} \mathrm{l^{-1 }}$ in the HS treatments with organisms present (Fig. 4). On the last day, however there was a dramatic increase of DCAA concentration in these treatments $\left(6.8\right.$ to $\left.7.4 \mu \mathrm{mol} \mathrm{l}^{-1}\right)$. In the control treatment with HS added there was a large increase in DCAA concentration (from 2.8 to $7.6 \mu$ mol $\mathrm{l}^{-1}$ ) during the experiment. We assume that the difference in DCAA concentration in the sterile control treatment with HS added and the HS treatments with organisms present was either due to bacterial transformation of DCAA to DFAA by extracellular aminopeptidases, or a utilization of DCAA by Alexandrium catenella.

\section{Total dissolved carbohydrates (TDCHO, glucose equivalents)}

The concentration of TDCHO was $0.2 \mathrm{mg} \mathrm{l}^{-1}$ in the initial seawater used for the experiment. The addi- 
tion of HS increased the TDCHO concentration to $0.4-0.6 \mathrm{mg} \mathrm{l}^{-1}$ (Fig. 5). In the control treatment without HS addition, there was a slight increase of TDCHO, while the concentration remained around $0.2 \mathrm{mg} \mathrm{l}^{-1}$ in the other treatments without HS added. In the HS treatments there was a continuous increase in the TDCHO concentration in the control (up to $0.8 \mathrm{mg} \mathrm{l}^{-1}$ at the end of the experiment), while in the treatments with bacteria, there was first an increase of TDCHO concentration to $0.6 \mathrm{mg} \mathrm{l}^{-1}$ during the first $2 \mathrm{~d}$, whereafter the concentration decreased. In the axenic Alexandrium catenella treatment with HS addition, the TDCHO concentration continued to increase until Day 5. There was a significantly lower TDCHO concentration in the treatments with bacteria (with or without $A$. catenella) than in the axenic $A$. catenella treatments at Day 7 ( $p<0.05$, Mann-Whitney $U$-test).
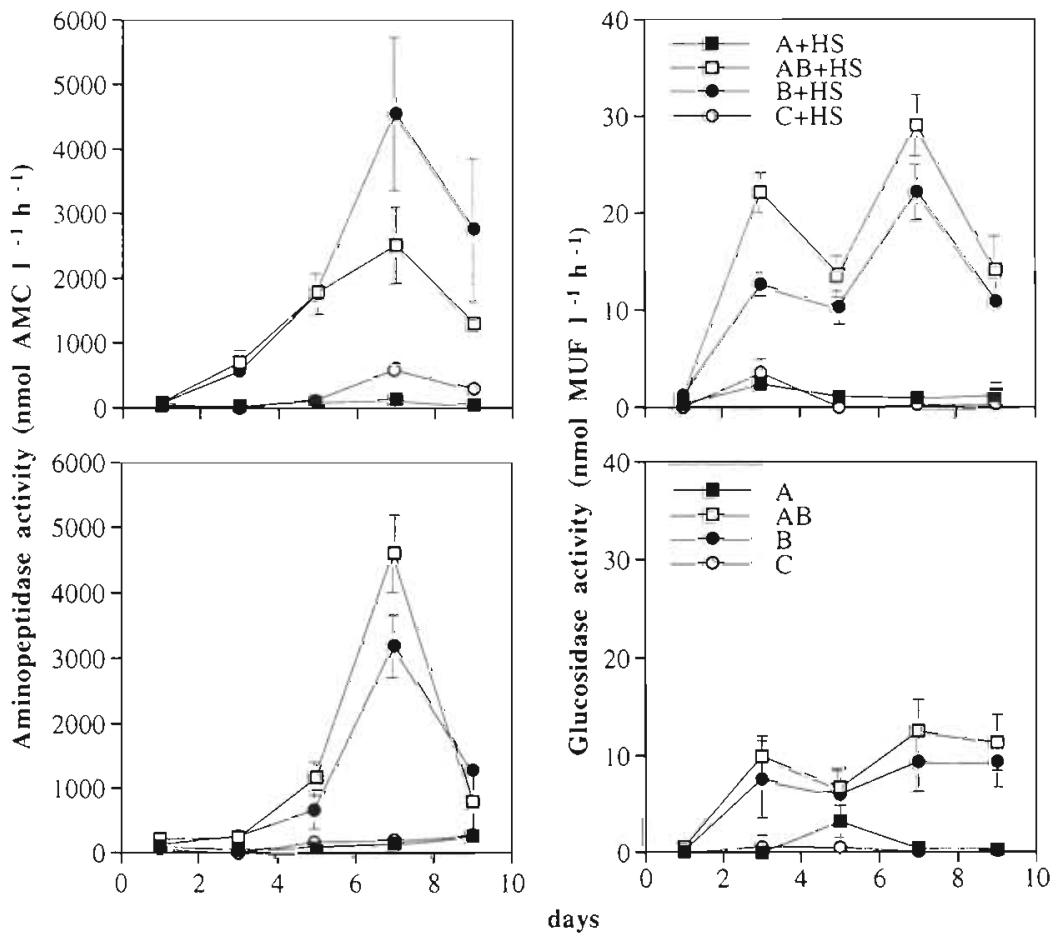

Fig. 6. Aminopeptidase and $\beta$-glucosidase activity. Treatments as in Fig. $2(n=4$, mean \pm SD)

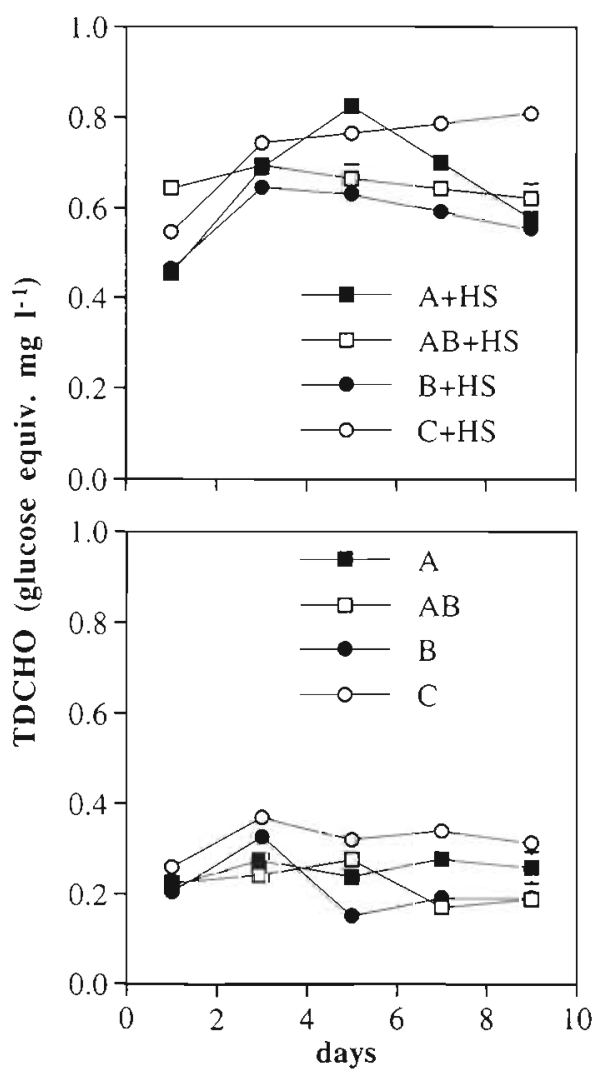

Fig. 5. Concentrations of total dissolved carbohydrates. Treatments as in Fig. $2(n=4$, mean $\pm S D)$

\section{Enzyme activities (aminopeptidase and $\beta$-glucosidase)}

Aminopeptidase activity increased during the incubation and reached maximum values in all treatments with bacteria at Day 7 (Fig. 6). Addition of HS stimulated aminopeptidase activity in the B+HS treatment from Days 3 to 7 (between 42 and $156 \%$ higher activity compared to the $\mathrm{B}$ treatment). On Day 7 the amino-

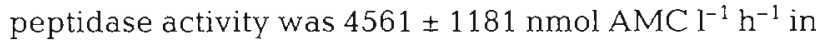
the $\mathrm{B}+\mathrm{HS}$ treatment compared to $3200 \pm 478 \mathrm{nmol}$ $A M \mathrm{~A} \mathrm{l}^{-1} \mathrm{~h}^{-1}$ in the $\mathrm{B}$ treatment. On Day 7 the aminopeptidase activity in $\mathrm{A}+\mathrm{HS}$ treatment was only $6 \%$ (147 nmol AMC $\mathrm{l}^{-1} \mathrm{~h}^{-1}$ ) of the activity in the $\mathrm{AB}+\mathrm{HS}$

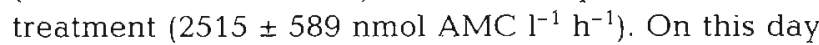
the activity in the control ( $\mathrm{C}+\mathrm{HS}$ ) was $14 \%$ of the activity in the $\mathrm{B}+\mathrm{HS}$ treatment. On one occasion (Day 7 ) a lower aminopeptidase activity in the HS treatments than the non HS treatments was observed. The aminopeptidase activity in the AB+HS treatments was $2515 \pm$

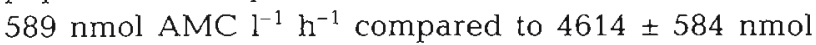
$\mathrm{AMC}^{-1} \mathrm{~h}^{-1}$ in the $\mathrm{AB}$ treatment. The aminopeptidase activity was also lower in the $A B+H S$ treatment than in the B+HS treatment on Days 7 and 9.

Addition of $H S$ stimulated $\beta$-glucosidase activity in the $\mathrm{B}+\mathrm{HS}$ treatment (between 63 and $137 \%$ higher activity than in the $B$ treatment during Days 3 to 7 ) as well as in the $\mathrm{AB}+\mathrm{HS}$ treatment (103 to $133 \%$ higher 
activity than in the $\mathrm{AB}$ treatment between Days 3 and 7) (Fig. 6). On Day 7 , the activity reached $22.2 \pm$ $2.9 \mathrm{nmol} \mathrm{MUF}{ }^{-1} \mathrm{~h}^{-1}$ in the B+HS treatment and $29.1 \pm$ $3.1 \mathrm{nmol} \mathrm{MUF} \mathrm{l}^{-1} \mathrm{~h}^{-1}$ in the $\mathrm{AB}+\mathrm{HS}$ treatment com-

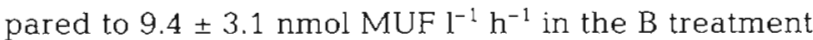
and $12.5 \pm 3.2 \mathrm{nmol} \mathrm{MUF} \mathrm{l}^{-1} \mathrm{~h}^{-1}$ in the $\mathrm{A}+\mathrm{B}$ treatment. Activity of $\beta$-glucosidase was higher in the treatments with both bacteria and Alexandrium catenella compared to treatments with only bacteria during the whole experimental period and the insignificant $\beta$ glucosidase activity in the $A+H S$ and $A$ treatment $(3 \%$ of the activity in the $A B+H S$ and $A B$ treatments on Day 7) confirms the axenity of the A. catenella treatments during the experimental period.

\section{DISCUSSION}

The riverine HS were to some extent available for bacterial degradation, as shown by the increased aminopeptidase and $\beta$-glucosidase activity. The enzymes provided the bacteria with easily assimilable $C$ and $N$ compounds, resulting in a significantly higher bacterial biomass in the HS treatments. The growth of Alexandrium catenella was also stimulated by the addition of HS, despite no algal or bacterial associated aminopeptidase activity in the axenic $A$. catenella treatment. The growth stimulation of $A$. catenella was partly due to uptake of released ammonium from the HS, but the major $N$ sources for $A$. catenella were DFAA and DCAA that were released from the HS, and perhaps also other $\mathrm{N}$-containing macromolecules as indicated by the uptake of fluorescently labeled dextrans (Legrand \& Carlsson 1998, this issue). The utilization of molecules larger than DFAA indicates a direct uptake by $A$. catenella, perhaps by pinocytosis.

\section{Release of amino acids and ammonium from the HS}

Initial concentrations of DFAA and DCAA were comparable to other studies in coastal waters (Dawson \& Pritchard 1978, Mopper \& Lindroth 1982, Coffin 1989). Later, there was a continuous increase of DFAA, DCAA and ammonium concentrations in the $\mathrm{C}+\mathrm{HS}$ treatment. Jørgensen et al. (1993) also found a substantial increase (around $1 \mu \mathrm{mol} \mathrm{l}^{-1}$ ) of DCAA concentration during $24 \mathrm{~h}$ in treatments with added HMW DOM (increasing the DOC concentration from 2.5 to $3.0 \mathrm{mg} \mathrm{l}^{-1}$ ). The reason for the concentration increase of amino acids in the HS controls was probably not due to photodegradation of the HS. Degradation of DOM subjected to UV light has been described by e.g. Kieber et al. (1989), and Kieber et al. (1990), but since the light intensity was low in our experiment (110 $\mathrm{\mu mol}$ $\mathrm{m}^{-2} \mathrm{~s}^{-1}$ ) and we used cool-white fluorescent tubes mainly emitting PAR irradiance, the concentration increase of DFAA and DCAA might instead have been caused by a chemical release of loosely bound/ adsorbed amino acids from the HS. According to Thurman (1985), 15 to $20 \%$ of the $\mathrm{N}$ in aquatic $\mathrm{HS}$ is in amino acids that are structurally a part of the HS by amide linkages, but both DFAA and DCAA also associate with the HS through labile hydrogen bonds which can be easily disrupted by changes in $\mathrm{pH}$. The extraction procedure we used to concentrate the HS would have caused a precipitation of the polypeptides in the river water due to the acidification of the sample before eluting it through the XAD column (Thurman 1985). Lytle \& Perdue (1981) also found that $97 \%$ of the amino acids present in river water would be extracted using the XAD extraction procedure. The release of amino acids during the incubation is in contrast to the observation by Carlson et al. (1985) that amino acid concentrations decreased by amino acids binding abiologically to dissolved macromolecular material in seawater. An explanation could be that our isolated HS had many more amino acids loosely associated than could be bound as described by Carlson et al. (1985) and that these amino acids were released from the HS when added to seawater. Ammonium was also released from the $\mathrm{HS}$ in the $\mathrm{C}+\mathrm{HS}$ treatment. This ammonium was also isolated together with the HS from the river water and was probably also loosely bound to or associated with the HS.

\section{Bacterial growth and utilization of ammonium, DCAA, DFAA and carbohydrates}

Bacterial growth was clearly stimulated by the addition of HS, since the bacteria immediately started to grow exponentially in the HS treatments. Bacterial utilization of HS is well known (e.g. De Haan 1974, Tranvik \& Sieburth 1989, Moran \& Hodson 1990), and bacterial utilization of these high-molecular-weight compounds has recently been shown to be higher than for low-molecular-weight compounds (Tranvik 1990, Amon \& Benner 1996). After $9 \mathrm{~d}$, the utilizable part of the DOM in the HS treatment with bacteria ( $B+H S)$ seems to have been exhausted, since the bacteria had reached stationary phase (probably either the available $\mathrm{C}$ or $\mathrm{N}$ became limiting). The biomass of bacteria present in this treatment had then increased by

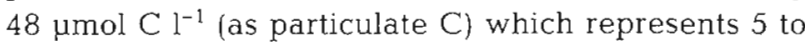
$6 \%$ of the initial DOC pool in the HS treatments. This is comparable to other estimates of the utilizable pool of $D O C$ in brackish water with a high DOM concentration (Zweifel et al. 1993), and for river water rich in HMW compounds (Amon \& Benner 1996). 
Assuming that the observed release of ammonium in the control treatment with HS added also took place in the other treatments, essentially all ammonium released in the B+HS treatment was utilized by bacteria. Ammonium is together with DFAA the most important N source for bacteria (e.g. Kirchman 1994), and assimilation of ammonium can be substantial even when a large pool of assimilable DON is present (Tupas \& Koike 1990).

The lower concentration of DCAA in the B+HS treatment compared to the control and the stimulation of aminopeptidase activity in this treatment shows that a transformation of DCAA to DFAA took place. Also, the lower concentration of DFAA in the B+HS treatment compared to the control indicates that bacteria utilized the DFAA. The $C$ and $N$ requirements of bacteria can be sustained by DFAA in priority to DCAA and ammonium, especially when easily assimilable $C$ compounds are available (Jørgensen et al. 1993, Middelboe et al. 1995). However, when the concentrations of DFAA are low, the contribution of DCAA as a C and N source becomes more important (Rosenstock \& Simon 1993). Also the growth phase of the bacteria affects the utilization of compounds. Middelboe et al. (1995) showed that DCAA are more important as a source for $N$ and $C$ in the stationary phase, while the importance of DFAA and ammonium decreases.

There was an increase in the concentration of TDCHO in the control treatments where HS was added during the experiment. Since TDCHO is readily used by planktonic bacteria and can support a substantial fraction of the $\mathrm{C}$ requirements for bacterial growth (Hanisch et al. 1996), the difference in TDCHO concentration between the control and the treatments with bacteria probably represents bacterial utilization of the TDCHO. A high $\beta$-glucosidase activity in the HS treatments with bacteria present also indicates a utilization of the TDCHO.

There seemed to be a higher bacterial abundance in the $\mathrm{AB}+\mathrm{HS}$ treatment, compared to the $\mathrm{B}+\mathrm{HS}$ treatment (though not statistically significant). Assuming that the release of TDCHO by the axenic Alexandrium catenella in the A+HS treatment also occurred in the $A B+H S$ treatment, and that the lower concentration of TDCHO in the $\mathrm{AB}+\mathrm{HS}$ treatment compared to the control represents TDCHO being utilized by bacteria, excretion of TDCHO by $A$. catenella also contributed somewhat to bacterial growth. This suggestion is supported by a higher $\beta$-glucosidase activity in the $\mathrm{AB}+\mathrm{HS}$ treatment compared to the $\mathrm{B}+\mathrm{HS}$ treatment.

\section{Enzyme activities}

The addition of HS stimulated bacterial aminopeptidase and $\beta$-glucosidase activity. In the treatments without bacteria there were no significant enzyme activities, as would be expected, since the extracellular aminopeptidases and $\beta$-glucosidases are associated with bacteria (e.g. Rosso \& Azam 1987, Chróst \& Rai 1993). The aminopeptidase and $\beta$-glucosidase activities in the treatments with bacteria are similar to values recorded during a mesocosm experiment with coastal water (aminopeptidase and $\beta$-glucosi-

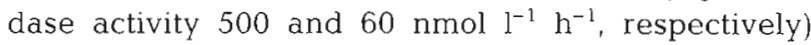
(Chróst \& Riemann 1994). However, enzyme activities measured in a humic lake were lower (aminopeptidase activity 20 to $30 \mathrm{nmol} \mathrm{l}^{-1} \mathrm{~h}^{-1}$ and $\beta$ glucosidase activity 70 to $120 \mathrm{nmol} \mathrm{l}^{-1} \mathrm{~h}^{-1}$ ) than in our experiment (Münster et al. 1989). Stimulation of enzyme activity by humic substances has been shown by Hoppe (1983), who measured higher aminopeptidase and $\beta$-glucosidase activity in a mangrove belt in the Caribbean coastal zone, compared to lagoon water with a high influence of seawater. However, bacterial extracellular enzymatic activity in the presence of HS can also be inhibited (Wetzel 1991, 1993)

Assuming that DCAA and TDCHO were released from the HS in the treatments with organisms present, as was observed in the $\mathrm{C}+\mathrm{HS}$ treatment, this release would have stimulated the aminopeptidase and $\beta$-glucosidase activity in the treatments with bacteria. This is in accordance with the correlation between aminopeptidase activity and DCAA concentration described by Münster et al. (1992) for a humic lake.

Annual studies often show a maxima of enzyme activities when the phytoplankton bloom breaks down (Chróst \& Overbeck 1987), when intracellular enzymes are released from algal cell lysis and excreted products stimulate the bacterial associated enzyme activities. This experiment ended when Alexandrium catenella and bacteria had started to reach stationary phase, but before any significant breakdown and release of intracellular aminopeptidases had started, which is indicated by the lack of aminopeptidase activity in the axenic $A$. catenella treatments, and consequently the higher enzyme activities in the $A B$ treatment without HS are probably due to a stimulation of bacterial associated enzymes caused by excretion of DCAA and TDCHO by $A$. catenella.

The stimulation of $\beta$-glucosidase activity in the $\mathrm{AB}+\mathrm{HS}$ treatment as well as the $\mathrm{B}+\mathrm{HS}$ treatment was probably due to the release of TDCHO from the HS as observed in the control treatment $(\mathrm{C}+\mathrm{HS})$. This is in accordance with results showing a positive correlation between the concentration of dissolved combined glucose concentrations and $\beta$-glucosidase activity (Münster et al. 1992). 


\section{Growth of Alexandrium catenella and utilization of inorganic and dissolved organic nitrogen}

The specific growth rate of Alexandrium catenella in the axenic treatment with HS added $\left(\mu=0.27 \mathrm{~d}^{-1}\right)$ was comparable to reported in situ growth rates for $A$. tamarense at $15^{\circ} \mathrm{C}\left(0.3 \mathrm{~d}^{-1}\right)$ (Watras et al. 1982) or growth rates obtained at laboratory conditions $(t=15$ to $16^{\circ} \mathrm{C}$; light intensity: 57 to $170 \mu \mathrm{mol} \mathrm{m} \mathrm{m}^{-2} \mathrm{~s}^{-1}$ ) when A. tamarense cells were supplied with a surplus of inorganic $N$ in the medium $\left(\mu=0.2\right.$ to $0.3 \mathrm{~d}^{-1}$ ) (Watras et al. 1982, Boczar et al. 1988). The growth rates we obtained are also comparable to growth rates for $A$. catenella in laboratory cultures with a surplus of inorganic $N$ in the medium $\left(\mu=0.2\right.$ to $0.4 \mathrm{~d}^{-1}$ ) (Proctor et al. 1975, Boczar et al. 1988, Matsuda et al. 1996).

The large release of both DFAA and DCAA in the controls where HS was added and no concentration increase of DFAA and DCAA in the treatment with Alexandrium catenella and $\mathrm{HS}$ indicate that $A$. catenella used the amino acids that were released from the HS. Direct utilization of small organic molecules, such as DFAA, has been shown to be an important mechanism for phytoplankton to obtain macronutrients (Flynn \& Butler 1986, Antia et al. 1991). High-molecularweight polymeric compounds, however, are too large to pass the cytoplasmic membrane (Payne 1980). Therefore, only that part of the DON that occurs in low molecular form (e.g. urea and amino acids) can be taken up directly through the cell membranes. Since there was no aminopeptidase activity in the axenic $A$. catenella treatment with HS added, $A$. catenella probably used the DCAA directly. Ogata et al. (1996) observed growth of $A$. tamarense when N-limited semi-continuous cultures were supplied with yeast extract and suggested that $A$. tamarense was able to utilize organic $\mathrm{N}$ substances for growth and toxin production. Kodama et al. (1996) showed the existence of actively growing endocellular bacteria in $A$. tamarense and suggested that these bacteria might have a mutualistic relationship with $A$. tamarense for utilization of organic substances. Jacobson \& Anderson (1996) presented evidence that Alexandrium ostenfeldii can ingest other organisms (ciliates and other dinoflagellates) using phagocytosis.

The mechanism by which Alexandrium catenella could utilize DCAA and perhaps other organic N compounds in the A+HS treatment is unknown. However, a direct uptake of dissolved organic macromolecules was demonstrated in connection to this experiment, using fluorescently labeled dextran molecules with a molecular weight of $2000 \mathrm{kDa}$ (Legrand \& Carlsson 1998). One possible mechanism for the uptake of HMW organic molecules is by pinocytosis whereby the plasma membrane from a cell extends and forms a vesicle enclosing liquid containing the HMW compounds. This process has been shown to exist in some phytoplankton species (Kivic \& Vesk 1974, Klut et al 1987). Larger organic molecules can be taken up via the pusule system by some flagellates, although the major function of this organelle is still unknown. Dunaliella tertiolecta, Amphidinium carterae and Prorocentrum micans have been shown to take up macromolecular markers such as labeled lectins and horseradish peroxidase, presumably by pinocytosis using the pusule system, where the macromolecules accumulated in vesicles inside the cell membrane (Klut et al. 1987). This process has not been studied to any significant extent among phytoplankton however, and it still remains an open question whether or not pinocytosis is of any significance in phytoplankton nutrition. For heterotrophic nanoflagellates, significant uptake of 'colloidal DOM' has been shown (Sherr 1988, Tranvik et al. 1993). In these experiments, fluorescent (FITC-labeled) macromolecules (carbohydrates and proteins) spanning a large range of molecular weights (50 to $2000 \mathrm{kDa}$ ) at concentrations similar to the ones occurring in marine waters were ingested by heterotrophic flagellates and supported growth.

\section{Interactions between Alexandrium catenella and bacteria}

Aminopeptidase activity was negligible in the axenic $A+$ HS treatment, but high in the $A B+H S$ treatment. Thus, in the AB+HS treatment, Alexandrium catenella might have used DFAA as an N source, helped by the bacterial aminopeptidases. However, since the growth of $A$. catenella was somewhat less in the AB+HS treatment than in the A+HS treatment, $A$. catenella probably did not benefit from the bacterial aminopeptidase activity. Instead, DFAA produced by the aminopeptidase activity in the treatments with both $A$. catenella and bacteria was probably mainly used by the bacteria as suggested by several earlier investigators (Hollibaugh \& Azam 1983, Chróst 1991, Chróst \& Rai 1993, Martinez \& Azam 1993)

Phytoplankton should potentially compete with bacteria for the utilization of amino acids, as well as for inorganic nutrients, and bacteria are supposed to be better competitors for nutrients at low concentrations because of their larger surface to volume ratio (Bratbak $\&$ Thingstad 1985). Since the bacterial half-saturation constants for amino acid uptake are lower $(0.01$ to $1.0 \mathrm{umol} \mathrm{l}^{-1}$ ) (Billen 1984) than the half-saturation constants of phytoplankton amino acid transport proteins (0.4 to $150 \mathrm{mmol} \mathrm{l}^{-1}$ ) (Flynn \& Butler 1986), it has also been assumed that amino acid uptake by phytoplankton is not important in the natural environment (Paul 
1983). However, as pointed out by Flynn \& Butler (1986), the measurements of phytoplankton halfsaturation constants for DFAA have been biased by using species adapted to high concentrations of inorganic nitrogen, and we do not know the capability of phytoplankton growing during the summer season in waters deprived of inorganic nitrogen to use DFAA as a nitrogen source. Palenik \& Morel (1990) also described cell-surface amino oxidases that would enable some phytoplankton to utilize DFAA at very low ambient concentrations (half-saturation constants of about $0.2 \mu \mathrm{mol} \mathrm{I}^{-1}$ ), which suggests that some phytoplankton can efficiently compete with bacteria for DFAA

In our experiment, Alexandrium catenella seemed to grow somewhat better in the A+HS treatment than in the $\mathrm{AB}+\mathrm{HS}$ treatment. Even if this was not statistically significant it indicates that bacteria and $A$. catenella to some extent were competing for the available N. However, the large release of ammonium and dissolved amino acids from the HS probably made this competition very weak during the rather short experimental time.

On the other hand, the bacteria grew better together with Alexandrium catenella than alone in the HS treatments, probably because $A$. catenella supplied the bacteria with easily assimilable $C$, such as carbohydrates (e.g. Myklestad \& Haug 1972, Obernosterer \& Herndl 1995), which the increasing concentrations of TDCHO in the A+HS treatment also indicate.

In the $\mathrm{B}+\mathrm{HS}$ treatment there was no net release of ammonia, even if the bacteria apparently were using the large release of DFAA and DCAA from the HS. Bacterial utilization of amino acids usually results in remineralization and excretion of ammonia since the $\mathrm{C}: \mathrm{N}$ ratio of amino acids is low (e.g. Goldman et al. 1987, Tupas \& Koike 1990). However, in the HS treatments the bacteria also had access to a large variety of organic substrates, with a much higher $\mathrm{C}: \mathrm{N}$ ratio than amino acids. Since there was no net accumulation of ammonia in any treatment with bacteria present, the available $C: N$ ratio of the substrates was probably so high that the bacteria kept the $N$, instead of remineralizing it, as shown by Goldman et al. (1987).

\section{CONCLUSIONS}

Both DFAA and DCAA can be released abiotically from riverine $H S$ reaching coastal waters and constitute an additional $\mathrm{N}$ source for phytoplankton capable of utilizing dissolved amino acids. Activity of marine bacterial extracellular enzymes (aminopeptidase and $\beta$-glucosidase) is stimulated by riverine HS and subsequent bacterial degradation of the HS supports a substantial bacterial growth, without remineralizing inorganic N. Alexandrium catenella can utilize organic nitrogen (DFAA, DCAA and perhaps other DON compounds) without bacteria present, and the utilization of larger DON compounds than DFAA by A catenella might involve an uptake mechanism for macromolecules, such as pinocytosis. This ability of $A$. catenella to directly utilize macromolecular $\mathrm{N}$ compounds in HS may be an advantage for this species (and perhaps other Alexandrium species) in coastal waters influenced by river runoff, and partly explain their occurrence and persistence in these waters.

Acknowledgements. We thank Lars- $\AA$ ke Gisselson for technical assistance and Ramunas Stepanauskas for helping us with the IP-Lab script to determine bacterial biovolumes. This study was supported by funds from the Swedish Environmental Protection Agency (SNV) (contract holders P.C. and Lars Tranvik/H.E.)

\section{LITERATURE CITED}

Allen HL (1976) Dissolved organic matter in lake water: characteristics of molecular weight size fractions and ecological implications. Oikos 27:64-70

Amon RMW, Benner R (1996) Bacterial utilization of different size classes of dissolved organic matter. Limnol Oceanogr 41:41-51

Andersson $\mathrm{T}$, Nilsson $\AA$, Jansson M (1991) Coloured substances in Swedish lakes and rivers-temporal variation and regulating factors. In: Allard B, Borén H, Grimvall A (eds) Humic substances in the aquatic and terrestrial environment. 33. Springer-Verlag, Berlin, p 243-253

Antia NJ, Harrison PJ, Oliviera L (1991) The role of dissolved organic nitrogen in phytoplankton nutrition, cell biology and ecology. Phycologia 30:1-89

Billen G (1984) Heterotrophic utilization and regeneration of nitrogen. In: Hobbie JE, Williams PJleB (eds) Heterotrophic activity in the sea. Plenum Press, New York, p 313-355

Boczar BA, Beitler MK, Liston J, Sullivan JJ, Cattolico RA (1988) Paralytic shellfish toxins in Protogonyaulax tamarensis and Protogonyaulax catenella in axenic culture Plant Physiol 88:1285-1290

Bratbak G, Thingstad TF (1985) Phytoplankton-bacteria interactions: an apparent paradox? Analysis of a model system with both competition and commensalism. Mar Ecol Prog Ser 25:23-30

Carlson DJ, Mayer LM, Brann ML, Mague TH (1985) Binding of monomeric organic compounds to macromolecular dissolved organic matter in seawater. Mar Chem 16:141-153

Carłsson P, Granéli E (1993) Availability of humic bound nitrogen for coastal phytoplankton. Estuar Coast Shelf Sci $36: 433-447$

Carlsson P, Granéli E, Tester P, Boni L (1995) Influences of riverine humic substances on bacteria, protozoa, phytoplankton, and copepods in a coastal plankton community Mar Ecol Prog Ser 127:213-221

Chróst RJ (1991) Environmental control of the synthesis and activity of aquatic microbial ectoenzymes. In: Chróst RJ (ed) Microbial enzymes in aquatic environments Springer-Verlag, New York, p 29-59 
Chróst RJ, Overbeck J (1987) Kinetics of alkaline phosphatase activity and phosphorus availability for phytoplankton and bacterioplankton in Lake Plußsee (North German eutrophic lake). Microb Ecol 13:229-248

Chróst RJ, Rai H (1993) Ectoenzyme activity and bacterial secondary production in nutrient-impoverished and nutrientenriched freshwater mesocosms. Microb Ecol 25:131-150

Chróst RJ, Riemann B (1994) Storm-stimulated enzymatic decomposition of organic matter in benthic/coastal mesocosms. Mar Ecol Prog Ser 108:185-192

Coffin RB (1989) Bacterial uptake of dissolved free and combined amino acids in estuarine waters. Limnol Oceanogr 34:531-542

Coffin RB, Connolly JP, Harris PS (1993) Availability of dissolved organic carbon to bacterioplankton examined by oxygen utilization. Mar Ecol Prog Ser 101:9-22

Dawson R, Pritchard RG (1978) The determination of $\alpha$-amino acids in seawater using a fluorometric analyser. Mar Chem 6:27-40

De Haan H (1974) Effects of a fulvic acid fraction on the growth of a Pseudomonas from Tjeukemeer (the Netherlands). Freshwat Biol 4:301-310

Deuser WG (1988) Whither organic carbon? Nature 332: $396-397$

Fleischer S, Stibe L (1989) Agriculture kills marine fish in the 1980 s. Who is responsible for fish kills in the year 2000 ? Ambio 6:347-350

Flynn KJ, Butler I (1986) Nitrogen sources for the growth of marine microalgae: role of dissolved free amino acids. Mar Ecol Prog Ser 34:281-304

Fraga $S$ (1993) Harmful algal blooms in relation to wind induced coastal upwelling and river plumes. ICES Coop Res Rep 206:35-43

Franks PJS, Anderson DM (1992) Alongshore transport of a toxic phytoplankton bloom in a buoyancy current: Alexandrium tamarense in the Gulf of Maine. Mar Biol 112: $153-164$

Goldman JC, Caron DA, Dennett MR (1987) Regulation of gross growth efficiency and ammonium regeneration in bacteria by substrate $\mathrm{C}: \mathrm{N}$ ratio. Limnol Oceanogr 32 : $1239-1252$

Granéli E, Edler L, Gedziorowska D, Nyman U (1985) Influence of humic and fulvic acids on Prorocentrum minimum (Pav.) Schiller. In: Anderson DM, White AW, Baden DG (eds) Toxic dinoflagellates. Elsevier, New York, p 201-206

Guillard RLL, Ryther JH (1962) Studies of marine planktonic diatoms I. Cyclotella nana Hustedt, and Detonula confervacea (Cleve) Gran. Can J Microbiol 8:229-239

Hanisch K, Schweitzer B, Simon M (1996) Use of dissolved carbohydrates by planktonic bacteria in a mesotrophic lake. Microb Ecol 31:41-55

Hedges JI (1987) Organic matter in sea water. Nature 330: 205-206

Hoch MP, Kirchman DL (1995) Ammonium uptake by heterotrophic bacteria in the Delaware estuary and adjacent coastal waters. Limnol Oceanogr 40:886-897

Hollibaugh JT, Azam F (1983) Microbial degradation of dissolved proteins in seawater. Limnol Oceanogr 28: $1104-1116$

Hoppe HG (1983) Significance of exoenzymatic activities in the ecology of brackish water: measurements by means of methylumbelliferyl-substrates. Mar Ecol Prog Ser 11: 299-308

Hoppe HG, Kim SJ, Gocke K (1988) Microbial decomposition in aquatic environments: combined process of extracellular enzyme activity and substrate uptake. Appl Environ Microbiol 54:784-790
Jacobson DM Anderson DM (1996) Widespread phagocytosis of ciliates and other protists by marine mixotrophic and heterotrophic thecate dinoflagellates. J Phycol 32: $279-285$

Jakobsen TR, Rai H (1991) Aminopeptidase activity in lakes of differing eutrophication. In: Chróst RJ (ed) Microbial enzymes in aquatic environments. Springer-Verlag, New York, p 155-164

Johnson KM. Sieburth JM (1977) Dissolved carbohydrate in sea water. I. A precise spectrophotometric analysis for monosaccharides. Mar Chem 5:1-13

Jørgensen NOG, Kroer $N_{1}$ Coffin RB, Yang $X_{4}$ Lee C (1993) Dissolved free amino acids, combined amino acids, and DNA as sources of carbon and nitrogen to marine bacteria. Mar Ecol Prog Ser 98:135-148

Kieber DJ, McDaniel J, Mopper K (1989) Photochemical source of biological substrates in sea water: implications for carbon cycling. Nature 341:637-639

Kieber RJ, Zhou X, Mopper K (1990) Formation of carbonyl compounds from UV-induced photodegradation of humic substances in natural waters: fate of riverine carbon in the sea. Limnol Oceanogr 35:1503-1515

Kirchman DL (1994) The uptake of inorganic nutrients by heterotrophic bacteria. Microb Ecol 28:255-271

Kirchman DL, Keil RG, Wheeler PA (1989) The effects of amino acids on ammonium utilization and regeneration by heterotrophic bacteria in the subarctic Pacific. Deep-Sea Res 36:1763-1776

Kivic PA, Vesk M (1974) Pinocytotic uptake of protein from the reservoir in Euglena. Arch Microbiol 96:155-159

Klut ME, Bisalputra T, Antia NJ (1987) Some observations on the structure and function of the dinoflagellate pusule. Can J Bot 65:736-744

Kodama M, Sakamoto S, Koike K (1996) Symbiosis of bacteria in Alexandrium tamarense. In: Yasumoto T, Oshima $Y$, Fukuyo $Y$ (eds) Harmful and toxic algal blooms. UNESCO, Paris, p 351-354

Kullberg A, Petersen RCJ (1987) Dissolved organic carbon, seston and macroinvertebrate drift in an acidified and limed humic stream. Freshwat Biol 17:553-564

Lee S, Fuhrman J (1987) Relationships between biovolume and biomass of naturally derived marine bacterioplankton. Appl Environ Microbiol 53:1298-1303

Lee SH (1993) Measurement of carbon and nitrogen biomass and biovolume from naturally derived marine bacterioplankton. In: Kemp PF, Sherr BF, Sherr EB, Cole JJ (eds) Handbook of methods in aquatic microbial ecology. Lewis Publishers, Boca Raton, p 319-325

Lindroth P. Mopper K (1979) High performance liquid chromatographic determination of subpicomole amounts of amino acids by pre-column fluorescence derivatization with o-phthaldialdehyde. Analyt Chem 51:1667-1674

Lytle CR, Perdue EM (1981) Free, proteinaceous, and humic bound amino acids in river water containing high concentrations of aquatic humus. Environ Sci Technol 15:224-228

Martinez J, Azam F (1993) Periplasmic aminopeptidase and alkaline phosphatase activities in a marine bacterium: implications for substrate processing in the sea. Mar Ecol Prog Ser 2:89-97

Matsuda A, Nishijima T, Fukami K (1996) Effects of nitrogen deficiency on the PSP production by Alexandrium catenella under axenic cultures. In: Yasumoto $T$, Oshima $Y$, Fukuyo Y (eds) Harmful and toxic algal blooms. UNESCO, Paris, p 305-308

Mayer LM (1989) Extracellular proteolytic enzyme activity in sediments of an intertidal mudflat. Limnol Oceanogr 34 $973-980$ 
Meybeck M (1982) Carbon, nitrogen, and phosphorus transport by world rivers. Am J Sci 282:401-450

Meyer JL, Edwards RT, Risley R (1987) Bacterial growth on dissolved organic carbon from a blackwater river. Microb Ecol 13:13-29

Middelboe M, Borch NH, Kirchman DL (1995) Bacterial utilization of dissolved free amino acids, dissolved combined amino acids and ammonium in the Delaware Bay estuary: effects of carbon and nitrogen limitation. Mar Ecol Prog Ser 128:109-120

Moita MT (1993) Development of toxic dinoflagellates in relation to upwelling patterns off Portugal. In: Smayda TJ, Shimizu Y (eds) Toxic phytoplankton blooms in the sea. Elsevier, Amsterdam, p 299-304

Mopper K, Lindroth P (1982) Diel and depth variations in dissolved free amino acids and ammonium in the Baltic Sea determined by shipboard HPLC analysis. Limnol Oceanogr 27:336-347

Moran MA, Hodson RE (1990) Bacterial production on humic and nonhumic components of dissolved organic carbon. Limnol Oceanogr 35:1744-1756

Münster U (1991) Extracellular enzyme activity in eutrophic and polyhumic lakes. In: Chróst RJ (eds) Microbial enzymes in aquatic environments. Springer-Verlag, New York, p 96-122

Münster U, Chróst RJ (1990) Origin, composition and microbial utilization of dissolved organic matter. In: Overbeck $J$, Chróst RJ (eds) Aquatic microbial ecology: biochemical and molecular approaches. Springer-Verlag, New York p $8-46$

Münster U, Einiö P, Nurminen J (1989) Evaluation of the measurements of extraceliular enzyme activities in a polyhumic lake by means of studies with 4-methylumbelliferylsubstrates. Arch Hydrobiol 115:321-337

Münster U, Einiö P, Nurminen J, Overbeck J (1992) Extracellular enzymes in a polyhumic lake: important regulators in detritus processing. Hydrobiologia 229:225-238

Myklestad S, Haug A. (1972) Production of carbohydrates by the marine diatom Chaetoceros affinis var. willey (Gran) Hustedt. I. Effect of the concentration of nutrients in the culture medium. J Exp Mar Biol Ecol 9:125-136

Obernosterer I, Herndl GJ (1995) Phytoplankton extracellular release and bacterial growth: dependence on the inorganic N/P ratio. Mar Ecol Prog Ser 116:247-257

Ogata T, Koike K, Nomura S, Kodama M (1996) Utilization of organic substances for growth and toxin production by Alexandrium tamarense. In: Yasumoto $T$, Oshima $Y$, Fukuyo Y (eds) Harmful and toxic algal blooms. UNESCO, Paris, p 343-346

Pages J, Gadel F (1990) Dissolved organic matter and UV absorption in a tropical hypersaline estuary. Sci Total Environ 99:173-204

Palenik B, Morel FMM (1990) Amino acid utilization by marine phytoplankton: a novel mechanism. Limnol Oceanogr 35: $260-269$

Paul JH (1983) Uptake of organic nitrogen. In: Carpenter EJ, Capone $G$ (eds) Nitrogen in the marine environment. Academic Press, New York, p 275-308

Payne JW (1980) Microorganisms and nitrogen sources. John Wiley and Sons, New York

Petersen RC Jr, Hargeby A, Kullberg A (1987) The biological role of humic material in acidified waters. A summary of the chemistry, biology and ecotoxicology of aquatic humus in acidified waters. Report, National Swedish Environmental Protection Board, Solna

Petty RL, Michel WC, Snow JP, Johnson KS (1982) Determination of total primary amines in seawater and plant nec- tar with flow injection sample processing and fluorescence detection. Anal Chim Acta 142:299-304

Porter KG, Feig YS (1980) The use of DAPI for identifying and counting aquatic microflora. Limnol Oceanogr 25: 943-948

Price NM, Cochlan WP, Harrison PJ (1985) Time course of uptake of inorganic and organic nitrogen by phytoplankton in the Strait of Georgia: comparison of frontal and stratified communities. Mar Ecol Prog Ser 27:39-53

Proctor NH, Chan SL, Trevor AJ (1975) Production of saxitoxin by cultures of Gonyaulax catenella. Toxicon 13:1-9

Ramsing NB, Fossing $\mathrm{H}$, Ferdelman TG, Andersen F, Thamdrup B (1996) Distribution of bacterial populations in a stratified fjord (Mariager Fjord, Denmark) quantified by in situ hybridization and related to chemical gradients in the water column. Appl Environ Microbiol 62:1391-1404

Rosenstock B. Simon M (1993) Use of dissolved combined and free amino acids by planktonic bacteria in Lake Constance. Limnol Oceanogr 38:1521-1531

Rosso AL, Azam F (1987) Proteolytic activity in coastal ocenanic waters: depth distributon and relationship to bacterial populations. Mar Ecol Prog Ser 41:231-240

Roth M (1971) Fluorescence reaction for amino acids. Analyt Chem 43:880-882

Sherr EB (1988) Direct use of high molecular weight polysaccharide by heterotrophic flagellates. Nature 335:348-351

Smetacek V (1975) Die Sukzession des Phytoplankton in der westlichen Kieler Bucht. PhD thesis, Univ Kiel

Thurman EM (1985) Organic geochemistry of natural waters. Martinus/Nijhoff/Dr W Junk Publishers, Boston

Thurman EM, Malcolm RL (1981) Preparative isolation of aquatic humic substances. Environ Sci Technol 15: 463-466

Thurman EM, Malcolm RL (1981) Structural study of humic substances: new approaches and methods. In: Christman RF, Gjessing ET (eds) Aquatic and terrestrial humic materials. Ann Arbor Science, Ann Arbor, p 1-23

Tranvik LJ (1990) Bacterioplankton growth on fractions of dissolved organic carbon of different molecular weights from humic and clear waters. Appl Environ Microbiol 56: $1672-1677$

Tranvik LJ, Sieburth JM (1989) Effects of flocculated humic matter on free and attached pelagic microorganisms. Limnol Oceanogr 34:688-699

Tranvik LJ, Sherr EB, Sherr BF (1993) Uptake and utilization of 'colloidal DOM' by heterotrophic flagellates in seawater. Mar Ecol Prog Ser 92:301-309

Tupas L, Koike I (1990) Amino acid and ammonium utilization by heterotrophic marine bacteria grown in enriched seawater. Limnol Oceanogr 35:1145-1155

Valderrama JC (1995) Methods of nutrient analysis. In: Hallegraeff GM, Anderson DM, Cembella AD (eds) Manual of harmful marine microalgae. IOC Manuals and guides No. 33. UNESCO, Paris, p 251-268

Watras CJ, Chisholm SW, Anderson DM (1982) Regulation of growth in an estuarine clone of Gonyaulax tamarensis Lebour: salinity-dependent temperature responses. J Exp Mar Biol Ecol 62:25-37

Wedborg M, Skoog A, Fogelqvist E (1994) Organic carbon and humic substances in the Baltic Sea, the Kattegatt, and the Skagerrak. In: Sienesi N, Miano TM (eds) Humic substances in the global environment and implications on human health. Elsevier, New York, p 917-924

Wetzel RG (1991) Extracellular enzymatic interactions: storage, redistribution, and interspecific communication. In: Chróst RJ (ed) Microbial enzymes in aquatic environments. Springer-Verlag, New York, p 6-28 
Wetzel RG (1993) Humic compounds from wetlands: complexation, inactivation, and reactivation of surface-bound and extracellular enzymes. Verh Int Verein Limnol 25: $122-128$

Ziechmann W (1988) Evolution of structural models from consideration of physical and chemical properties. In: Frim-

Editorial responsibility: Robert Sanders,

Philadelphia, Pennsylvania, USA mel FH, Christman RF (eds) Humic substances and their role in the environment. John Wiley \& Sons Limited, Chichester, p 113-132

Zweifel UL, Norrman B, Hagström $\AA$ (1993) Consumption of dissolved organic carbon by marine bacteria and demand for inorganic nutrients. Mar Ecol Prog Ser 101:23-32

Submitted: October 8, 1997; Accepted: March 9, 1998

Proofs received from author(s): August 6, 1998 